\title{
Competition law enforcement under informational asymmetry
}

\author{
Rainer Kulms ${ }^{1}$
}

Published online: 15 December 2016

(C) The Author(s) 2016. This article is published with open access at Springerlink.com

\begin{abstract}
Competition law enforcement, whether by public officials, private parties and consumers or the courts, has to resolve informational and resource asymmetries. Current EU competition law establishes an interface between government enforcement action and private litigation. For the EU Commission, informational asymmetries will be primarily addressed under positive comity agreements with other countries and its leniency programme. For private parties, the success of a stand-alone or follow-on action for damages critically depends on disclosure of documents. The Court of Justice of the European Union attempts to strike a balance between disclosure and the Commission's preference for confidentiality. Nonetheless, the EU law concept of effectiveness and equivalence of competition law enforcement does not supersede national law rules on procedure or liability of private parties. The Court of Justice applies a negative harmonisation strategy towards national laws. Where appropriate, the paper will assess enforcement practice under U.S. law.
\end{abstract}

Keywords Competition law · Public and private enforcement · Law of procedure · Discovery and comity

\footnotetext{
This article is based on a presentation given at the 3rd China-EU Legal Forum (CELF) which took place at the Supreme Court of Cassation in Rome on 8./9.9.2015. The 3rd CELF was co-organised by the China Law Society, the Bar Association of Rome, the International Institute for the Unification of Private Law (UNIDROIT), the China-EU School of Law at the China University of Political Science and Law and the College of Comparative Law at the China University of Political Science and Law).
}

Rainer Kulms

kulms@mpipriv.de

1 Max Planck Institute for Comparative and International Private Law, Hamburg, Germany 


\section{Competition enforcement policy: the scenario}

\subsection{The players}

EU competition policy enforcement has become a multi-player game between Union and Member State officials, private businesses, consumers ${ }^{1}$ and national courts. ${ }^{2}$ Regulation (EC) No. 1/2003 replaced Commission-centred enforcement by a system of parallel competences between Member State and EU authorities. A European Competition Network has been set up to address informational and resource asymmetries between national enforcement authorities and the Commission: Cases are allocated and information on ongoing investigations is exchanged. ${ }^{3}$ The activities within the European Competition Network demonstrate that the current focus on public v. private enforcement of competition law needs to be supplemented by an analysis of intergovernmental arrangements for cross-border coordination of investigation and enforcement activities. ${ }^{4}$ International cooperation is motivated by a concern for efficient competition law enforcement. ${ }^{5}$ It is also driven by the quest for judge-proof evidence in the face of information and resource asymmetries. ${ }^{6}$

Directive 2014/104/EU on private actions for damages for breaches of EU antitrust law ensures the "effectiveness of the competition rules" by private enforcement. ${ }^{7}$ Access to documents held by competition enforcement authorities

\footnotetext{
${ }^{1}$ Cf. on the objectives of competition law from the angle of consumer protection: Buttigieg 20097 et seq., 65 et seq.

${ }^{2}$ See EU Commission Notice on the co-operation between the Commission and the courts of the EU Member States in the application of Articles 81 and 82 EC (2004/C 101/04) 2004. For empirical data on enforcement decisions by the EU Commission and Member States' competition authorities: European Commission, Communication from the Commission to the European Parliament and the Council, Ten Years of Antitrust Enforcement under Regulation 1/2003: Achievements and Future Perspectives (COM(2014) 453) 2014b (available at http://ec.europa.eu/competition/antitrust/legislation/antitrust_ enforcement_10_years_en.pdf), and the accompanying EU Commission Staff Working Document, Enhancing competition enforcement by the Member States' competition authorities: institutional and procedural issues (SWD(2014) 231/4) 2014a (available at http://ec.europa.eu/competition/antitrust/ legislation/swd_2014_231_en.pdf).

${ }^{3}$ See Council and the Commission Joint Statement of the on the Functioning of the Network of Competition Authorities 2002 available at http://ec.europa.eu/competition/ecn/joint_statement_en.pdf), and $\S 3$ of the : Merger Review of the EU Merger Working Group, adopted on 8 November 2011 (available at http://ec.europa.eu/competition/ecn/nca_best_practices_merger_review_en.pdf). For a critical assessment see Munari 2014 at p. 111 et seq.

${ }^{4}$ Cf. Munari 2014117 et seq., noting that each national competition enforcement authority operates within the framework of its domestic national laws). On the private international law implications of cross-border antitrust enforcement: Basedow Francq Idot 20121 et seq.

${ }^{5}$ See OECD Recommendation of the OECD of 16 September 2014 concerning International Cooperation on Competition Investigations and Proceedings [C(2014)108] 2014a (available at http://www. oecd.org/daf/competition/2014-rec-internat-coop-competition.pdf).

${ }^{6}$ See OECD, Challenges of International Co-operation on Competition Law Enforcement 2014b (available at http://www.oecd.org/competition/challenges-international-coop-competition-2014.htm).

${ }^{7}$ Recital (6) of the Directive 2014/104/EU of the European Parliament and of the Council of 26 November 2014 on certain rules governing actions for damages under national law for infringements of the competition law provisions of the Member States and the European Union, O.J. L 349/1 of 5 December 2014.
} 
and private parties is vital for alleviating information asymmetries in private litigation, in both common and civil law jurisdictions. ${ }^{8}$ Case law from the Court of Justice of the European Union (CJEU) indicates that private parties wish to improve their evidentiary position by gaining access to Commission documents. ${ }^{9}$ But parties may be frustrated by an unclear relationship between public and private enforcement, between EU competition law and national rules of substance on civil liability $^{10}$ and reluctance from the European Competition Network. ${ }^{11}$

\subsection{Outline of the paper}

This paper will first review the implications of informational and resource asymmetries for public and private enforcement. It will then assess the challenges of cross-border enforcement as public officials will have to account for the impact of globalisation, different regulatory approaches and the need to exchange information under traditional concepts of sovereignty and modern notions of comity.

Antitrust law enforcement is to ensure that substantive concepts of competition and free markets will be upheld. But the day-to-day practice of public and private enforcement reveals that the law of procedure plays an important role in handling informational asymmetry. The function of pleading requirements in the light of directive 2014/104/EU, discovery and burden of proof rules and cost aspects will be assessed. The interplay between rebuttable presumptions, evidence and law of substance will be extended to parent-subsidiary relationships where competition law enforcement has to handle informational asymmetries under conglomerate structures and the single-unit entity doctrine. A section on collective redress mechanisms to overcome resource asymmetries concludes.

\section{Law enforcement under informational and resource asymmetry}

\subsection{The basics of public and private enforcement}

Enforcement decisions by public authorities are the result of a policy choice in the face of informational and resource asymmetries. ${ }^{12}$ In a study on antitrust enforcement Besanko and Spulber assess the optimal policy design where collusive behaviour cannot be observed and the information on production costs is private $^{13}$ : Under these circumstances enforcement agencies will have to

\footnotetext{
${ }^{8}$ See studies by Cortese 2014a, b, c, Munari 2014 and Pace 2014.

9 See infra sub 2.4.

${ }^{10}$ Cf. Cortese 2014a, b, c 146 et seq. and Pace 2014244 et seq. and infra sub II.4., 5. and III.1., 2.

11 See Resolution of the Meeting of the Heads of the European Competition Authorities of 23 May 2012, Protection of leniency material in the context of civil damages actions (available at http://ec.europa.eu/ competition/ecn/leniency_material_protection_en.pdf).

$12 \mathrm{Cf}$. on the use of antitrust law in order to address economic inequality due to information asymmetry: Newman 2014854 et seq.

13 Besanko, Spulber 1989408 et seq.
} 
tolerate a certain degree of collusion although the law classifies price fixing as illegal per se. ${ }^{14}$ Nonetheless, enforcement authorities should maintain a high profile of prosecuting cases for the sake of credibility ${ }^{15}$ even if the social benefits are relatively small in relation to the deterrence. ${ }^{16}$ An economic analysis of the concepts of harm and damages in antitrust shows that public and private enforcement have to be mindful of interface between deterrence to others and compensation. ${ }^{17}$ The EU Commission's focus on certain industries and 'innovative' anticompetitive practices reflects a realistic assessment of its enforcement capacities. $^{18}$ The Commission will concentrate on business activities where enforcement officials have discerned a high probability of success in their fight against cartels. ${ }^{19}$ In a cross-border scenario the enforcement strategies depend on the Commission's ability to resolve informational asymmetries by engineering positive comity agreements with other countries. ${ }^{20}$

The best price-fixing conspiracies operate on the paucity of public information. $^{21}$ Win rates in private enforcement litigation are related to the plaintiff's ability to come up with sufficient information about defendants' anticompetitive behaviour. $^{22}$ Win rates are also determined by a meaningful relationship between substantive law of antitrust and national laws rules on civil procedure. ${ }^{23}$ This is not just a matter of carving out residues of national law-making in the face of EU law. ${ }^{24}$ It is also a policy question (and one of economic analysis) whether private enforcement supplements or undermines competition policies by public authorities. $^{25}$ If the statutory pleading requirement is fulfilled as soon as a private plaintiff establishes legal sufficiency of the complaint, private antitrust enforcement would be more prevalent. ${ }^{26}$ If, on the other hand, successful pleading depends on the strength of the evidence offered by the plaintiff, private standalone litigation on anticompetitive behaviour will be scarce: Private plaintiffs will not master the threshold of factual sufficiency without some limited discovery. ${ }^{27}$

\footnotetext{
14 Pénard, Squam 2002214.

15 For an empirical analysis of the Commission's enforcement practice Hüschelrath 201425 et seq.

16 Cf. Besanko, Spulber 1989 421et seq.; Pénard, Squam 2002215.

17 Eger, Weise 2010153; Wagner 2007618 et seq. and Eger 2007674 et seq.

18 See European Commission, Communication from the Commission to the European Parliament and the Council, Ten Years of Antitrust Enforcement under Regulation 1/2003: Achievements and Future Perspectives (COM(2014) 453) 2014b (available at http://ec.europa.eu/competition/antitrust/legislation/ antitrust_enforcement_10_years_en.pdf), no. 4.

19 For a critical assessment of Commission's current policy on fines Bosch 201456 et seq.

${ }^{20}$ See infra sub 2.2 .

21 Picker 2007165.

22 Hylton 2002154 et seq. See generally on competitor's motives for initiating litigation against an antitrust law infringer: Sokol 2012703 et seq.

23 Cf. Wagner 2007610.

24 Cf. Cisotta 2015 94, Kwan 2014457.

25 Eger 2007675.

26 Cf. Webb v. Nashville Area Habitat for Humanity, Inc., 346 SW 3d 422 (432) (Tenn., 2011).

27 State of Tennessee v. NV Sumatra Tobacco Trading Company, 403 SW 3d 726 (768 FN 1) (Tenn., 2013).
} 
But amicus interventions by public competition authorities might help private plaintiffs to overcome their difficulties. ${ }^{28}$

\subsection{Cross-border enforcement: comity agreements}

Antitrust conspirators appear to relish the legal complexities of cross-border infringements where "international antitrust claims are difficult, costly and time consuming". ${ }^{29}$ U.S. judges reject the notion of a customary international law of antitrust, ${ }^{30}$ relegating parties and their informational asymmetries to their respective national jurisdictions. National enforcement agencies have chosen practical cooperation, exchange of information and 'positive comity' agreements over theory and lack of consensus on international antitrust principles. ${ }^{31}$ Over the past 20 years the U.S. and the EU have concluded a series of agreements on 'positive comity' with their major trading partners, ${ }^{32}$ including the People's Republic of China. ${ }^{33}$ Most agreements enshrine a notification duty when enforcement activities might affect important interests of the other party. In the US-EU context, the 1998 comity agreement provides for the deferral of envisaged enforcement activities by one party if the other party has enforcement activities pending. ${ }^{34}$ The European Court of First Instance has held that

\footnotetext{
${ }^{28}$ Cf. on amicus-curiae inventions by the Commission and national competition authorities: European Commission 2014 b Staff Working Document, Ten Years of Antitrust Enforcement under Regulation 1/2003, and Cortese 2014a, b, c 152 et seq.

29 In re Vitamin C Antitrust Litigation, 2013 WL 6191965 (E.D.N.Y., 2013).

30 In re Microsoft Corp. Antitrust Litigation, 127 FS 2d 702 (D. Md., 2001); Empagran S.A. v. HoffmanLa Roche, Ltd., 2001 WL 761360 (D.D.C., 2001).

31 See the OECD's assessment of the legal instruments for formal cross-border cooperation: OECD 2014a, and the OECD Recommendation on Co-operation on Competition Investigations and Proceedings 2014c (available at http://www.oecd.org/competition/international-coop-competition-2014recommendation.htm).

32 See the list of Antitrust Cooperation Agreements published on the homepage of the U.S. Department of Justice at http://www.justice.gov/atr/antitrust-cooperation-agreements (as of 31 July 2015), and the list of Agreements on the EU Commission's Homepage 'Bilateral relations on competition issues', available at http://ec.europa.eu/competition/international/bilateral/.

33 Memorandum of Understanding on Antitrust and Antimonopoly Cooperation between the United States Department of Justice and Federal Trade Commission on the one hand and the People's Republic of China National Development and Reform Commission, Ministry of Commerce, and State Administration for Industry and Commerce, on the other hand, of 27 July 2011 (available at https:// www.ftc.gov/system/files/110726mou-english.pdf). The Sino-US Memorandum does not go as far as the positive comity agreements with other countries. It pledges to establish a dialogue on competition law enforcement without prescribing intensive cooperation mechanisms of a 'comity' context. Nonetheless, the Memorandum does not foreclose an exchange of information on specific enforcement issues or on anti-competition proceedings by either side. A confidentiality clause has been inserted into the Memorandum. From a Sino-European perspective see the Memorandum of Understanding on Cooperation in the area of anti-monopoly law between on the one side The European Commission (DirectorateGeneral for Competition) and on the other side The National Development and Reform Commission and the State Administration for Industry and Commerce of the People's Republic of China of 20 September 2012 (available at http://ec.europa.eu/competition/international/bilateral/mou_china_en.pdf).

34 Art. IV of the Agreement between the Government of the United States of America and the European Communities on the Application of Positive Comity Principles in the Enforcement of their Competition Laws of 3/4 June 1998 (available at https://www.ftc.gov/policy/cooperation-agreements/us-europeancommission-enhanced-positive-comity-agreement).
} 
the Agreement does not enshrine the principle ne bis in idem: According to the Court, the legal interests protected by EU and US authorities are not identical. The sole purpose of the Agreement is to ensure that one of the parties might benefit from the practical effects of a procedure commenced by the enforcement authorities of the other party. ${ }^{35}$ The US-EU 2011 "Best Practices on Cooperation in Merger Investigations"36 provide for cooperative investigation mechanisms whereby the Reviewing Agencies should agree on a timetable for regular inter-agency consultations in order to guarantee an equal level of information with respect to the economic data of an envisaged crossborder merger. ${ }^{37}$

\subsection{Transatlantic antitrust enforcement: concepts and cases}

Since the late 1990s there has been an increasing awareness on both sides of the Atlantic that cooperation and coordination have the potential of reducing asymmetry and forum-shopping by antitrust infringers and consumer groups. ${ }^{38}$ However, crossborder cooperation and coordinated enforcement strategies will not always bridge policy differences on anti-competitive behaviour: The failed General ElectricHoneywell merger taught the industry and enforcement officials that close cooperation and an exchange of information are no guarantee for consistent decisions by US and European antitrust agencies. ${ }^{39}$

\subsubsection{Cooperation and coordination}

In the WorldCom/MCI merger case an acquisition had taken place so that $80 \%$ of the US domestic long-distance market was controlled by three providers. Moreover, WorldCom was in a position with a small group of providers to dominate private international line services to and from the US. ${ }^{40}$ As soon as the merger plan had

\footnotetext{
35 European Court of First Instance (Second Chamber), judgment of 15 June 2005, Tokai Carbon Co., Ltd. et al. v. Commission of the European Communities, joined cases T-71/03, T-74/03, T-87/03 and T-91/03, recital no. 116, confirmed by European Court of Justice (Fourth Chamber) (with respect to case no. T-71/03), judgment of 10 May 2007, case no. C-328/05P, sub nomine SGL Carbon AG v. Commission of the European Communities, [2007] ECR I-3955 et seq.

36 US-EU Merger Working Group, Best Practices on Cooperation in Merger Investigations of 14 October 2011 (available at http://ec.europa.eu/competition/mergers/legislation/best_practices_2011_en.pdf and at https://www.ftc.gov/system/files/111014eumerger.pdf), and FTC Press Release of 14 October 2011 (Washington, D.C.), United States and European Union Antitrust Agencies Issue Revised Best Practices for Coordinating Merger Reviews - Agencies Celebrate 20th Anniversary of Cooperation Agreement (available at https://www.ftc.gov/news-events/press-releases/2011/10/united-states-and-european-unionantitrust-agencies-issue-revised).

37 See II.6 and III of the Best Practices.

38 See Bingham, Assistant Attorney General, Antitrust Division, U.S. Department of Justice 1994 Statement before the Committee on the Judiciary, U.S. Senate, Concerning the International Antitrust Enforcement Assistance Act of 1994, Washington, D.C. 4 August 1994 (available at www.justice.gov/atr/ public/speeches/akbspch2.txt).

39 See address by James, Assistant Attorney General, U.S. Department of Justice 2001 International Antitrust in the 21st Century: Cooperation and Convergence, Address before the OECD Global Forum on Competition, Paris, 17 October 2001 (available at http://www.justice.gov/atr/public/speeches/9330.htm).

40 See In re Sprint Corporation Securities Litigation, 232 FS 2d 1193 (1200 et seq.) (D. Kansas, 2002).
} 
been notified with the US Department of Justice and the EU Commission, the parties waived their confidentiality rights. ${ }^{41}$ Both US authorities and the EU Commission reacted negatively when WorldCom announced plans to take over a diversified telecommunications corporation (Sprint) with long distance, local and wireless communication services. ${ }^{42}$ There was substantial cooperation between the agencies, including exchanges of views on the analytical framework, coordinated requests for information and attendance of US and Commission officials at hearings in Brussels and Washington. ${ }^{43}$ Ultimately, the Commission prohibited the merger between MCI WorldCom and Sprint. ${ }^{44}$ There was also close cooperation between US enforcement agencies and the EU Commission when the US aluminium producer Alcoa Inc. acquired Reynolds Metals Inc. ${ }^{45}$ : The Commission approved the merger, but requested assurances from Alcoa to divest itself of certain activities. $^{46}$

The 2007 fight against international price-fixing practices in the freight forwarding services industry for air cargo is the result of coordinated raids by antitrust enforcement officials in US, Europe, South Africa and Japan. ${ }^{47}$ Similarly, coordinated activities took place in abolishing a price fixing cartel between air carriers. ${ }^{48}$ One of the members of the cartels made an application to the US Department of Justice and the European Commission to benefit from their respective corporate leniency programmes. ${ }^{49}$ The applicant airline had approached the US Department of Justice to avoid criminal liability, treble damages and joint and several liability for the co-conspirators. ${ }^{50}$ Although the facts had clearly established antitrust violations on both sides of the Atlantic, the plaintiffs of a private class action against the airline defendant found it difficult to meet the

\footnotetext{
${ }^{41}$ Ibid. at p.1200 et seq. See also European Commission, Case No. COMP/M.1741-MCI WorldCom/ Sprint, Regulation (EEC) No. 4064/89 - Merger Procedure (Brussels, 28 June 2000) (available at http:// ec.europa.eu/competition/mergers/cases/decisions/m1741_en.pdf).

42 Ibid.

43 Ibid.

44 Ibid. and European Commission, Press Release, Commission prohibits merger between MCI WorldCom and Sprint (Brussels, 28 June 2000 (IP/00/668)) (available at http://europa.eu/rapid/pressrelease_IP-00-668_en.htm).

45 James 2001.

46 Commission Decision of 3 May 2000 declaring a concentration to be compatible with the common market and the EEA Agreement, Case No. COMP/M. 1693 - Alcoa/Reynolds, O.J. L 58/25 of 28 February 2002.

47 Precision Associates, Inc. v. Panalpina World Transport (Holding), Ltd. 2011 WL 7053807 (E.D.N.Y., 2011), see also European Commission Press Release, Antitrust: Commission imposes $€ 169$ million fine on freight forwarders for operating four price fixing cartels (Brussels, 28 March 2012 (IP/12/314)) (available at http://europa.eu/rapid/press-release_IP-12-314_en.htm).

48 See the decision of the EU Commission: Commission Decision of 9 November 2011, Case COMP/ 39258 - Airfreight (available at http://ec.europa.eu/competition/antitrust/cases/dec_docs/39258/39258_ 7008_7.pdf., Summary of the Decision in O.J. C 371/11 of 18 October 2014).

49 See In re Air Cargo Shipping Services Antitrust Litigation, 2008 WL 5958061 (E.D.N.Y., 2008).

50 Ibid.
} 
pleading requirements for bringing a case before a US court. ${ }^{51}$ Coordinated investigations between enforcement of several countries may also establish that no anti-competitive behaviour could be found and criminal charges will not be brought. $^{52}$

\subsubsection{Discovery and comity}

Private plaintiffs have attempted to take a free ride on the exchange of information established under the positive comity agreements. European victims of anticompetitive behaviour seek to buttress their position before the EU Commission by relying on discovery proceedings in the US, tacitly assuming that courts will condone discovery without insisting on the procedures under the Hague Evidence Convention. ${ }^{53}$ From the perspective of the EU Commission, a request for discovery before a foreign court tends to undermine the efficiency of an antitrust investigation. In their attitude towards comity US courts have shifted from leniency towards discovery to being more receptive to foreign governments' pleas for protecting the secrecy of an ongoing investigation. ${ }^{54}$

\subsubsection{Discovery of government documents in the US: Vitamins I Under rule 26} (b) of the Federal Rules of Civil Procedure ${ }^{55}$ parties enjoy broad discovery privileges. ${ }^{56}$ In the Richmark case, the US Court of Appeals for the $9^{\text {th }}$ Circuit upheld a judgment against a Chinese corporation which had been ordered to disclose information on its worldwide assets. ${ }^{57}$ The Circuit Court applied a three-pronged

\footnotetext{
51 Ibid. See also In re Urethane Antitrust Litigation, 683 FS 2d 1214 (1220 et seq.) (D. Kansas, 2010): Potential class members may not gain jurisdiction before a US court even if private enforcement of antitrust claims in the Member States of the European Union is still in its infancy.

52 See the US Department of Justice, the Canadian Competition Bureau and the European Commission investigating an alleged price-fixing conspiracy: In re Ethylene Propylene Diene Monomer (EPDM) Antitrust Litigation, 681 FS 2d 141 (147 et seq.) (D. Conn., 2009).

53 The Convention on the Taking of Evidence in Civil or Commercial Matters, The Hague, 18 March 1970 (available at http://www.hcch.net/index_de.php?act=conventions.text\&cid=82). See the analysis in Société Nationale Industrielle Aérospatiale v. U.S. District Court for the Southern District for Iowa, 482 U.S. 522 et seq. (1987) and In re Vitamins Antitrust Litigation, 120 FS 2d 45 (47 et seq.) (D.D.C., 2000).

54 Cf. Miller, Nordlander, Owens 20104 et seq.

55 See 26 (b) of the Federal Rule of Civil Procedure (as of 1 December 2014, available at www.uscourts. gov/file/rules-civil-procedure):

“DISCOVERY SCOPE AND LIMITS.

(1) Scope in General. Unless otherwise limited by court order, the scope of discovery is as follows:

Parties may obtain discovery regarding any non-privileged matter that is relevant to any party's claim or defense-including the existence, description, nature, custody, condition, and location of any documents or other tangible things and the identity and location of persons who know of any discoverable matter. For good cause, the court may order discovery of any matter relevant to the subject matter involved in the action. Relevant information need not be admissible at the trial if the discovery appears reasonably calculated to lead to the discovery of admissible evidence. All discovery is subject to the limitations imposed by Rule 26(b)(2)(C)".

56 See Miller, Nordlander, Owens 2010 et seq. For an analysis of the problems of extraterritorial discovery: Iontecheva 2001888 et seq.

57 Richmark Corp. v. Timber Falling Consultants et al., 959 F.2d 1468 (1471 et seq.) (9th Cir. 1992).
} 
test in order to ascertain whether the Chinese defendant had to disclose the requested information although it had claimed its capacity as an instrumentality of the Chinese government would exempt it from discovery. Under the Richmark holding, the location of information and parties, the possibility of obtaining information elsewhere and the balance of national interests are controlling.

The Vitamins cartel cases involved an international conspiracy to fix consumer prices in the USA and abroad. ${ }^{58}$ When it came to discovery, U.S. courts acknowledged that international comity might militate against enforcing a discovery order for disclosing foreign documents. But ultimately the courts did not block discovery of foreign documents. ${ }^{59}$ The European Commission, amongst others, had filed amicus briefs arguing against the disclosure of documents which were the object of ongoing antitrust investigations by the EU enforcement officials. ${ }^{60}$ The EU Commission emphasised that disclosure of the corporate documents would jeopardise its leniency programme and the cooperation with its US counterparts in the interest of efficient global antitrust law enforcement. ${ }^{61}$ Moreover, the EU Commission explained to the court that accepting discovery in principle would also prejudice future investigations and coordination and cooperation of joint EU-US enforcement strategies. ${ }^{62}$ The District Court disagreed. ${ }^{63}$

\subsubsection{Vitamins II: discovery of EU documents in the US after Empagran When} the Vitamins case reached the U.S. Supreme Court, ${ }^{64}$ the Court advanced a comityinspired reading of the Sherman Act, the relevant US antitrust statute. In order to accept US jurisdiction the Court insists on a domestic injury caused by foreign anticompetitive conduct. ${ }^{65}$ Conversely, if there is domestic anticompetitive conduct which does not create foreign injury, US courts will not help. ${ }^{66}$ Plaintiffs may not seek discovery if the success of their claim is predicated upon foreign independent harm. So far, the Supreme Court has not opined on how plaintiffs will fare if the domestic effects of the incriminated anticompetitive behaviour are linked to the foreign harm. ${ }^{67}$ Some courts have solved this query by requiring that in a pricefixing conspiracy increased prices in the US must proximately cause foreign injuries

\footnotetext{
58 For an account see First 2008 712; cf. Destautels-Stein 2008530 et seq.), and In re Vitamins Antitrust Litigation, 120 FS 2d 45 (47 et seq.) (D.D.C., 2000).

59 See the account by Goldman, Hersh, Witterick 20056 et seq. (2005).

${ }^{60}$ In re Vitamins Antitrust Litigation, 2002 WL 35021999 (D.D.C., 2002).

61 Ibid.

62 Ibid.

63 Ibid. See the different factual setting of the Canada-related conspiracy: In re Vitamins Antitrust Litigation, 216 F.R.D. 168 (D.D.C., 2003).

64 Hoffmann-La Roche v. Empagran S.A. et al., 542 U.S. 155 (2004) (At that stage, the case involved five distributors of vitamins from Ukraine, Australia, Ecuador and Panama, having allegedly participated in a price-fixing conspiracy).

65 Ibid., at p. 165 et seq.

66 Ibid., at p. 175.

67 In re Vitamin C Antitrust Litigation, 904 FS 2d 310 (319) (E.D.N.Y., 2012).
} 
to the plaintiff. ${ }^{68}$ This requirement is not met if the domestic effects of a global conspiracy caused foreign injuries due to indivisible global market for the relevant merchandise. $^{69}$

It seems that, after Empagran, US judges have become more amenable for a comity argument advanced in an amicus brief by the European Commission. In the Rubber Chemicals Antitrust Litigation ${ }^{70}$ the European affiliate of an US corporation had approached the European Commission for immunity under the leniency programme. The European affiliate produced documents to the Commission which contained information on US and Canadian investigations. The Korean plaintiff, a competitor of the US corporation, moved to compel discovery of the documents submitted to the EU Commission. The court objected on comity grounds. Citing the Richmark criteria, ${ }^{71}$ the court noted that the requested documents had not originated in the US and that the defendant had produced some documents which it transmitted to the US Department of Justice. ${ }^{72}$ In emphasising comity considerations, the court accepted the EU Commission's argument that the discovery of its documents would jeopardise the US-EU cooperation in the enforcement of antitrust laws and rejected the motion to compel discovery. ${ }^{73}$

In the Cathode Ray Tube (CRT) Antitrust Litigation the direct purchasers sought to compel discovery of a non-published EU decision directed at the US defendant who had participated in an international price-fixing conspiracy. ${ }^{74}$ The court decided in favour of comity and non-disclosure, since the European Commission had a vital interest in maintaining the confidentiality of some parts of the decision. ${ }^{75}$ Comity also dictates a rejection if the motion to compel discovery would seriously harm the EU's investigation process of anticompetitive behaviour and circumvent the European rules to access to file. ${ }^{76}$ Two recent cases highlight the problems the EU Commission might face in the context of international cartels. In a Delaware case on the consequences of an international price-fixing cartel, the EU Commission had complied with the request of a local court for international assistance. ${ }^{77}$ The Commission transmitted the redacted decision (i.e. without the confidential parts) to the court. ${ }^{78}$ This redacted decision enabled the plaintiff to supplement some of the

\footnotetext{
68 Ibid., at p. 319.

69 In re Graphite Electrodes Antitrust Litigation, 2007 WL 137684 (E.D. Pa., 2007); see also In re Hydrogen Peroxide Antitrust Litigation, 702 FS 2 d 548 (559 et seq.) (E.D. Pa., 2010), and Empagran S.A. v. Hoffman-La Roche Ltd, 417 F. 3d 1267 (1270 et seq.) (D.C. Cir., 2005) ("Empagran II").

70 In re Rubber Chemicals Antitrust Litigation, 486 FS 2d 1078 (1082 et seq.) (N.D. Cal., 2007). See also In re Intel Corp. Microprocessor Antitrust Litigation, 2008 WL 4861544 (D. Del., 2008).

71 See 959 F.2d 1468 (1471 et seq.).

72 In re Rubber Chemicals Antitrust Litigation, 486 FS 2d 1078 (1083).

73 Ibid., at p. 1084 .

74 In re Cathode Ray Tube (CRT) Antitrust Litigation, 2014 WL 1247770 (N.D. Cal., 2014).

75 Ibid. See also In re Payment Card Interchange Fee and Merchant Discount Antitrust Litigation, 2010 WL 3420517 (E.D.N.Y., 2010).

76 In re Application of Microsoft Corporation, 428 FS 2d 188 (194 seq.) (S.D.N.Y., 2006), citing from the amicus brief of the Directorate-General for Competition of the EU Commission.

77 Vichi v. Koninklijke Philips Electronics, 85 A. 3d 725 (751 et seq.) (Del. Ch., 2014).

78 Ibid.
} 
confidential information which was in his possession in order to make his complaint more successful. ${ }^{79}$ Ultimately the court granted him permission to amend his pleadings. ${ }^{80}$ The message of this case had not been lost on the Commission. In a follow-up case, the Commission warned the defendants that it would oppose any request for discovery of a redacted decision since this would violate EU Commission rules and Member State policy. ${ }^{81}$ The U.S. court obliged. ${ }^{82}$

\subsection{Access to public documents and discovery under directive 2014/104/EU}

Efficient enforcement of rights depends crucially on access to information, contained in both public and private files. ${ }^{83}$ Disclosure is the flip side of the ECJ's (as it then was) recognition of an individual's right to claim damages with respect to a breach of the EU's competition rules. ${ }^{84}$ Chapter II of Directive 2014/104/EU advocates a bifurcated approach towards disclosure of evidence and problems of informational asymmetry. Under art. 5 (1) Member States are required to introduce rules on discovery or rather, to empower national courts to order the plaintiff, the defendant, or a third party to disclose relevant evidence under their control. ${ }^{85}$ In issuing such orders, national courts shall be guided by proportionality concerns in order to avoid fishing expeditions. ${ }^{86}$ Art. 6 of the Directive 2014/104/EU prescribes rules on granting access to documents held by competition authorities. A special regime is envisaged for leniency statements and settlement submissions. While a party in litigation or a third party cannot request the disclosure of leniency statement or a settlement submission, the court may be requested to scrutinise the documents in camera in order to ascertain whether the documents deserve confidentiality protection. ${ }^{87}$ According to art. 6 (2) of the Directive, the new disclosure regime shall not affect rules and practices on public access to documents under Regulation (EC)

\footnotetext{
79 Ibid., at p. 755 et seq.

80 Ibid., at p. 758.

81 In re Cathode Ray Tube (CRT) Antitrust Litigation, 2014 WL 6602711 (N.D. Cal., 2014).

82 Ibid.

83 See the carefully balanced approach chosen by the CJEU in its judgment of 6 June 2013 (First Chamber) case no. C-536/11, Bundeswettbewerbsbehörde v. Donau Chemie AG at el., para. 30 et seq.

84 See the ECJ, judgments of 20 September 2001, case no. C-453/99, Courage Ltd. v. Bernard Crehan and Bernard Crehan v. Courage Ltd., [2001] I-6297, of 13 July 2006 (Third Chamber), joined cases C-295-298/04, Vincenzo Manfredi v. Lloyd Adriatico Assicurazioni SpA, [2006] ECR I-6619, of 6 November 2012 (Grand Chamber), case no. C-199/11, European Community v. Otis NV et al., para. 41 et seq. and of 14 June 2011 (Grand Chamber), case no. C-360/09, Pfleiderer AG v. Bundeskartellamt, para. 28 et seq.

85 See on the Dutch rules on the disclosure of evidence: Cumming, Freudenthal 2010202 et seq., and on English disclosure rules in competition law cases: ibid., at p. 256 et seq.

86 See art. 5 (3) of the Directive 2014/104/EU.

${ }^{87}$ See art. 6 (7) of the Directive.
} 
no. 1049/2001 which fleshes out art. 15 (3) TFEU ${ }^{88}$ on access to documents of the European Union. ${ }^{89}$

In the Pfleiderer case from Germany, the applicant had made an application to the Bundeskartellamt, the federal antitrust enforcement agency, to gain access to the documents relating to leniency procedures. ${ }^{90}$ The CJEU rejects a flat refusal to

88 Art. 15 (3) of the Treaty on European Union and on the Functioning of the European Union (O.J. C $326 / 1$ of 26 October 2012):

"3. Any citizen of the Union, and any natural or legal person residing or having its registered office in a Member State, shall have a right of access to documents of the Union's institutions, bodies, offices and agencies, whatever their medium, subject to the principles and the conditions to be defined in accordance with this paragraph.

General principles and limits on grounds of public or private interest governing this right of access to documents shall be determined by the European Parliament and the Council, by means of regulations, acting in accordance with the ordinary legislative procedure.

Each institution, body, office or agency shall ensure that its proceedings are transparent and shall elaborate in its own Rules of Procedure specific provisions regarding access to its documents, in accordance with the regulations referred to in the second subparagraph.

The Court of Justice of the European Union, the European Central Bank and the European Investment Bank shall be subject to this paragraph only when exercising their administrative tasks.

The European Parliament and the Council shall ensure publication of the documents relating to the legislative procedures under the terms laid down by the regulations referred to in the second subparagraph."

89 Regulation (EC) no. 1049/2001 of the European Parliament and of the Council of 30 May 2001 regarding public access to European Parliament, Council and Commission documents, O.J. L 145/43 of 31 May 2001. See artt. 1 and 2 of this Regulation:

"Article 1

Purpose

The purpose of this Regulation is:

(a) to define the principles, conditions and limits on grounds of public or private interest governing the right of access to European Parliament, Council and Commission (hereinafter referred to as "the institutions") documents provided for in Article 255 of the EC Treaty in such a way as to ensure the widest possible access to documents,

(b) to establish rules ensuring the easiest possible exercise of this right, and

(c) to promote good administrative practice on access to documents.

Article 2

Beneficiaries and scope

1. Any citizen of the Union, and any natural or legal person residing or having its registered office in a Member State, has a right of access to documents of the institutions, subject to the principles, conditions and limits defined in this Regulation.

2. The institutions may, subject to the same principles, conditions and limits, grant access to documents to any natural or legal person not residing or not having its registered office in a Member State.

3. This Regulation shall apply to all documents held by an institution, that is to say, documents drawn up or received by it and in its possession, in all areas of activity of the European Union.

4. Without prejudice to Articles 4 and 9, documents shall be made accessible to the public either following a written application or directly in electronic form or through a register. In particular, documents drawn up or received in the course of a legislative procedure shall be made directly accessible in accordance with Article 12.

5. Sensitive documents as defined in Article 9(1) shall be subject to special treatment in accordance with that Article.

6. This Regulation shall be without prejudice to rights of public access to documents held by the institutions which might follow from instruments of international law or acts of the institutions implementing them."

90 CJEU (Grand Chamber), judgment of 14 June 2011, case no. C-360/09, Pfleiderer AG v. Bundeskartellamt, [2011] ECR I-05161. 
access to leniency files. ${ }^{91}$ But the court adds a caveat: In granting access to the files on a case-by-case approach national authorities are entitled to protect other relevant interests in the face of the claims of a person adversely affected by anticompetitive behaviour. ${ }^{92}$ On the other hand, a consumer organisation which considers an action for damages before a national court may not be denied access to the Commission's files without a prior ad-hoc examination of the quality of the requested documents and the potential need for confidentiality. ${ }^{93}$ Subsequently, the CJEU has attempted to calibrate the Commission's interest in protecting the confidentiality of its investigations and leniency programmes against private interests to obtain information to initiate litigation for damages. ${ }^{94}$ The Court authorises the Commission to operate with a presumption of confidentiality which private parties have to rebut. ${ }^{95}$ This has led the Commission to classify documents into several categories of confidentiality. ${ }^{96}$ In the Axa case, an insurance company had requested access to more than 3000 documents held by the Commission. The CJEU accepted that the Commission had provided the insurance company with a table of contents relating to the documents filed with the Commission. ${ }^{97}$ Under the current state of jurisprudence, neither the Commission nor national courts may adopt a rigid and inflexible approach in balancing private parties' rights to access to public documents against the public interest in protecting confidentiality. ${ }^{98}$ This is also due to the uneasy relationship between the law on the Commission's enforcement activities and Member States' private law rules for follow-on proceedings. ${ }^{99}$

In several cases, the CJEU has opined on the requirements private parties have to fulfil in order to rebut the presumption of confidentiality. The private plaintiff will have to demonstrate that the requested information cannot be obtained elsewhere but from access to the Commission's files. ${ }^{100}$ It is as yet unclear whether this

\footnotetext{
91 Ibid., at para. 24 et seq. See EnBW Energie Baden-Württemberg et al., case no. T-344/08, CJEU judgment of the General Coiurt (Fourth Chamber) of 22 May 2012.

92 Ibid.

93 European Court of First Instance (First Chamber, Extended Composition), judgment of 13 April 2005, case no. C-T 2/03, Verein für Konsumenteninformation v. Commission.

94 See the balancing test suggested by the European Court (Third Chamber) in its judgment of 7 July 2015, case no- T-677/13, AXA Versicherung AG v. Commission, para. 66 et seq.

95 CJEU (General Court-Third Chamber), judgment of 15 July 2015, case no. T-462/12, Pilkington Group Ltd. v. Commission, para. 47 et seq. See also decision of the President of the CJEU of 11 March 2013, case no. T-462/12 R, Pilkington Group Ltd. v. Commission, at para. 44 (application for protective order to maintain the confidentiality of information cleared for disclosure).

96 Ibid., at para. 6, and Opinion of Advocate-General Pedro Cruz Villalón of 14 April 2015, case no. C612/13 P, Client Earth v. Commission, at para. 55.

97 Axa Versicherung AG v.Commission, case no. T-677/13. See also CJEU judgment of the General Court (Fourth Chamber) of 15 December 2011, CDC Hydrogene Peroxide Cartel Damage Claims (CDC Hydrogene Peroxide), case no.T-437/08.

98 Ibid., para. 123.

99 See infra sub 3.

100 Axa Versicherung v. Commission, at para. 76; judgment of the CJEU (Third Chamber), of 27 February 2014, case no. C-365 12 P, Commission v. EnBW Energie Baden-Württemberg AG; and judgment of 6 June 2013, case no. C-536/11 (First Chamber), Bundeswettbewerbsbehörde v. Donau Chemie AG et al., paras. 32 and 44.
} 
requirement should be read as relegating a private plaintiff to a motion for discovery before the competent civil court before access to public files can be sought. In National Grid Electricity Transmission Plc v. ABB Ltd. et al., the English High Court acknowledged the Commission's concern about disclosure of leniency materials. ${ }^{101}$ Nonetheless, the Court questioned the Commission's exclusive jurisdiction to determine whether documents submitted under the EU's leniency could be disclosed. The judge proceeded to a study of the materials and eventually decided that some documents should be disclosed. ${ }^{102}$ English disclosure rules are subject to proportionality considerations. ${ }^{103}$ With respect to disclosure in follow-on litigation for damages, the Court of Appeal will not require a party to establish the strength of its case prior to disclosure. ${ }^{104}$

\subsection{Information on parent-subsidiary relationships}

EU antitrust law does not sanction intra-enterprise conspiracies. The prohibition in art. 101 (1) TFEU is triggered once anticompetitive "agreements between undertakings, decisions by associations of undertakings (or) concerted practices"105 can be found. Art. 101 (1) does not build on the concept of a company, a firm or a legal person. ${ }^{106}$ Thus an agreement between undertakings of a conglomerate in a parent-subsidiary relationship is beyond the scope of art. 101 (1) TFEU "if the undertakings form an economic unit within which the subsidiary cannot (freely determine) its ... market (strategy) and ... the agreements ... are merely concerned with the allocation of tasks as between the undertakings". ${ }^{107}$ However, both, the CJEU and the Commission have refined this concept for the parent's liability for its subsidiary's anticompetitive behaviour (single economic unit doctrine) ${ }^{108}$ : Once a parent-subsidiary relationship has been recognised, the parent company will be held liable for anticompetitive behaviour of its subsidiary when it comes to imposing a fine. $^{109}$

\footnotetext{
${ }^{101}$ [2012] E.C.C. $12(\mathrm{Ch})$, sub no. 29 et seq.

102 Ibid., sub no. 56 et seq.

103 Kwan 2014458.

${ }^{104}$ Cooper Tire \& Rubber Co. Europe Ltd. v. Shell Chemicals UK Ltd. [2011] C.P. Rep. 1, sub no. 34 et seq. (CA Civ.), KME Yorkshire Ltd. et al. v. Toshiba Carrier UK Ltd. et al. [2012] EWCA Civ 1190, sub no. 32 et seq., and see Cisotta 201594.

105 Art. 101 (1) TFEU.

106 CJEU, judgments of 18 July 2013, case no. C-501/11 P (Fifth Chamber), Schindler Holding Ltd. et al. v. Commission, sub para. 102 (available at http://curia.europa.eu/juris/document/document.jsf?text= \&docid=139754\&pageIndex $=0 \&$ doclang=en \&mode $=1$ st $\&$ dir $=\& o c c=$ first $\&$ part $=1 \& c i d=554690)$, and of 10 April 2014, case C-233/11 P (Fourth Chamber), Commission v. Siemens AG Österreich et al. (available at http://curia.europa.eu/juris/document/document.jsf?text=\&docid=150784\&pageIndex $=$ 0\&doclang=en\&mode $=1$ st $\&$ dir $=\& o c c=$ first $\&$ part $=1 \&$ cid $=432926)$.

107 ECJ, judgment of 10 October 1978, case no. 3/78, Centrafarm BV v. American Home Products [1974] ECR 1147.

${ }^{108}$ See the comprehensive analysis of the case law by Faull, Kjølbye in: Faull, Nikpay 2014 at $\S 3.49$ et seq.

109 CJEU (Second Chamber), judgment of 20 September 2011, case no. C-521/09 P, Elf Aquitaine S.A. v. Commission, [2011] ECR I-8947 et seq. (at para. 88).
} 
The jurisprudence of the CJEU makes it abundantly clear that the 'single economic unit doctrine' operates as an investigative device for the Commission to overcome informational asymmetries arising from intricate conglomerate structures. ${ }^{110}$ There is a rebuttable presumption that a $100 \%$ subsidiary is under the direct control of the parent company. ${ }^{111}$ The CJEU will only accept counter-evidence to upset this presumption if evidence can be adduced that, in spite of the ownership structure, the subsidiary was entirely free in developing its business strategy and taking management decision. ${ }^{112}$ The single-economic entity doctrine is not confined to $100 \%$ subsidiaries. Participations beyond $50 \%$ may also establish a presumption in favour of the single-economic entity doctrine as long as there is evidence that the parent company controls the decision-making process so that the subsidiary is deprived of any discretion to determine its business strategies. ${ }^{113}$ A single-economic entity is also deemed to exist where a corporation participates in an operating company with several others and none of them has a majority, but one participating company can veto the decisions of another. ${ }^{114}$

The 'single economic unit doctrine' has far-reaching implications when it comes to calculating the fines for a breach of EU antitrust law. EU law departs from the concept of personal liability to the extent that a parent company will have to suffer the imposition of a fine for the anticompetitive behaviour of its subsidiary, if the latter is part and parcel of the parent's economic unit. ${ }^{115}$ The technical device for imputing such responsibility is the concept of joint and several liability which is intended to reflect the economic realities in a conglomerate. ${ }^{116}$ Thus, if the Commission finds that participation of the subsidiary justifies a reduction of the fine, the parent company shall also benefit from such a reduction if the parent company did not engineer the anticompetitive behaviour and is only held liable under tie imputation rules. $^{117}$

Under U.S. law, control issues are also vital in the context of motions to compel discovery. Private plaintiffs often seek to force the parent company to make a

\footnotetext{
110 Ibid., and judgments of 10 September 2009 (ECJ-Third Chamber), case no. C-97/08 P, Akzo Nobel NV et al. v. Commission, at para. 61 et seq., and of 16 November 2000 (ECJ-Fifth Chamber), case no. C-286/98 P, Stora Kopparbergs Bergslags v. Commission, [2000] ECR I-9945 et seq., at para. 29.

111 CJEU (Fifth Chamber), judgment of 18 July 2013, case no. C-501/11 P, Schindler Holding et al. v. Commission, at para. 109 et seq.

112 Ibid.

113 Faull, Kjølbye, Leopold and Nikpay, in: Faull, Nikpay $2014 \S 3.65$.

114 Ibid., at $\$ 3.66$.

115 See CJEU (Grand Chamber) judgment of 26 November 2013, case no. C-50/12 P, Kendrion NV v. Commission, paras. 44 et seq., 55 et seq., and the analysis of the CJEU's case law in the opinion of 30 May 2013 by Advocate-General E. Sharpston, para. 40 et seq.

116 See analysis in CJEU (Fourth Chamber), judgment of 10 April 2014, case C-233/11 P, Commission v. Siemens et al., supra, and judgment of the CJEU (General Court-Fourth Chamber) of 15 July 2015, case no. T-189/10, GEA Group AG v. Commission, para. 81 et seq.

117 CJEU (General Court-Fourth Chamber), judgment of 16 September 2013, case no. T-411/10, Laufen Austria AG v. Commission, para. 228 et seq., see also judgment of 19 June 2014 (First Chamber), case no. C-243/12 P, FLS Plast A/S v. Commission, at para. 85 et seq., and judgment of the Court (Fifth Chamber) of 17 September 2015, case no. C-597-13 P, Total SA v. Commission, recitals 38 et seq., and case note by Ahrens 2015872 et seq.
} 
subsidiary disclose the documents which the subsidiary has in its possession. This is especially apposite where the subsidiary and the parent company are of different nationalities and reside in different countries. ${ }^{118}$ Control for the purpose of compelling discovery is "the legal right to obtain documents upon demand". ${ }^{119}$ A parent company which owns $43.8 \%$ of the shares of its subsidiary and nominates only a minority on the board of directors has not control over its subsidiary. ${ }^{120}$ Conversely, the percentage of shares owned is not conclusive if the contractual relationship is such that the minority shareholder has the legal possibility of determining the decision-making process of the other corporation. If the relevant contracts establish a principal-agent relationship, the principal can be forced to disclose documents on the agent irrespective of the size of the participation. ${ }^{121}$

U.S. law holds some important comparative messages for the EU's interface between substantive antitrust law and the national law of procedure and substance. In 1984, the U.S. Supreme Court held that the parent company and its wholly owned subsidiary were not capable of engaging in an anticompetitive agreement. ${ }^{122}$ Initially, the U.S. Department of Justice accepted the logic of this holding, both from a jurisdictional and a liability perspective. ${ }^{123}$ Later, U.S. courts came to challenge the liability implications of the single economic unit theory. ${ }^{124}$ They now allow evidence that the parent company did in fact not have complete control over its subsidiary ${ }^{125}$; hence the possibility that even in a conglomerate structure an anticompetitive conspiracy with liability sanctions is possible. ${ }^{126}$

The Delaware Chancery Court has added an interesting ${ }^{127}$ alternative to the EU's single economic unit doctrine for discovery and liability purposes ${ }^{128}$ : The EU Commission had issued a decision against the members of a price-fixing cartel under the single-economic unit doctrine, but it remained unclear whether there had been additional fraudulent behaviour by one of the participants in the cartel. The

\footnotetext{
118 See analysis of case law in Strom v. American Honda Motor Co., Inc., 423 Mass. 330 (336 et seq.) (Mass., 1996).

119 US v. International Union of Petroleum \& Indus. Workers, 870 F. 2d 1450 (1452) (9 (th $^{\text {Cir., }}$ 1989); In re Citric Acid Litigation, 191 F. 3d 1090 (1107) (9 ${ }^{\text {th }}$ Cir., 1999).

${ }^{120}$ In re Uranium Antitrust Litigation, 480 FS 1138 (1152) (N.D. Ill., 1979).

121 St. Jude Medical S.C., Inc. v. Janssen-Counotte, 2015 WL 2359568 (D. Or., 2015).

122 Copperweld Corporation v. Independence Tube Corporation, 467 U.S. 752 (771 et seq.) (1984).

123 Cf. U.S. Department of Justice, Economic Analysis Group, Discussion Paper on Organization, Control and the Single Economic Entity Defense in Antitrust by D.V. Williamson (EAG 06-4-January 2006) (available at http://www.justice.gov/atr/organization-control-and-single-entity-defense-antitrust).

124 See analysis in Cox v. Cache County, 2013 WL 4854450 (D. Utah, 2013).

125 See also the US Supreme court analysing whether a corporation had "unitary decision-making quality or the single aggregation of economic power characteristic of independent action": American Needle, Inc v. National Football League et al, 560 U.S. 183 (196 et seq.) (2010).

126 See the detailed analysis in: Crosby v. Hospital of Valdosta and Lowndes County, 93 F. 3d 1515 (1526 et seq.) (11 ${ }^{\text {th }}$ Cir., 1996). As a corollary, courts have allowed suits by indirect purchasers to sue for damages, since the parent company would not allow its subsidiary to file suit: In re TFT-LCD (Flat Panel) Antitrust Litigation, 2011 WL 5357906 (N.D. Cal., 2011).

127 See the discussion in Cox v. Cache County, 2013 WL 4854450 (D. Utah, 2013).

128 Vichi v. Koninklijke Philips Electronics, N.V., 85 A. 3d 725 (781 et seq.) (Del. Ch., 2014).
} 
Delaware court explained that it would accept the preclusive effects of the EU's decision in as far as a violation of EU competition law had been determined. ${ }^{129}$ However, the court expressly denies the preclusive effect of the findings of the decision in as far as the plaintiff sought to attack 'additional' criminal behaviour. ${ }^{130}$ It is unclear whether the judge actually disapproves of the EU law's technique of imputing liability to a co-conspirator. But the Delaware case sends an interesting message for follow-on proceedings under Directive 2014/104/EU. Findings under the single-economic unit doctrine may not categorically preclude additional evidence in a follow-on litigation for damages.

In 2014, the CJEU emphasised that the single economic unit approach does not offer much guidance in resolving internal liability issues between the members of the unit which have been held jointly and severally liable by the Commission. After calculating the fine jointly and severally owed by the members of the single economic unit the Commission has no power to allocate percentage-wise 'shares of liability' to the various individual members of the single economic unit. This formidable task is left to the national judges construing their respective private law liability regimes. ${ }^{131}$ Under the current state of law it is unclear what the "effectiveness and equivalence" criterion ${ }^{132}$ of the Directive 2014/104/EU requires the Member States to do under the fall-out from the single economic entity doctrine. From a practical perspective, national courts will have to decide to what extent substantive national private law and rules of civil procedure require a limitation of single-economic-unit thinking. ${ }^{133}$ In his analysis of the CJEU's jurisprudence Bernardo Cortese has shown that it is not a foregone conclusion that Member States' courts will automatically extend the Commission's single economic-unit doctrine to follow-on proceedings for litigation. ${ }^{134}$ For him, the effectiveness of competition law enforcement would not be jeopardised if the single economic-unit doctrine does not extend to an antitrust version of corporate veil-piercing. ${ }^{135}$ For the English Court of Appeal, the Commission's single-economic-unit doctrine does not compel English domestic corporate law to assume that the act of one company in a

\footnotetext{
129 Ibid., at p. 782.

130 Ibid., at p. 783.

131 CJEU judgment of 10 April 2014, joined cases C-231-233/11, Siemens. See also judgment of 5 June 2014, case no. C-557/12 (Fifth Chamber), Kone AG et al. v. ÖBB-Infrastruktur GmbH, para. 32 et seq.: This applies also to causation criteria which have to be fleshed out in accordance with national legal principles, but may not jeopardise the effectiveness of European competition law.

132 Cf. the sceptical analysis by Pace 2014247 et seq.

133 The CJEU has authorised the Commission, however, to differentiate between the members of a single economic unit. A subsidiary cooperating with the Commission under the Leniency Programme may claim a reduction of the regular fine whereas the non-cooperating parent company may not: CJEU judgment of 19 June 2014, case no. C-243/12 P, FLS Plast A/S v. Commission, para. 87.

134 Cortese 2014 b 83 et seq., 89 et seq.

135 Ibid., at p. 91 et seq.
} 
conglomerate is "automatically the act of any other group of that group". ${ }^{136}$ Disclosure has to precede the analysis of the strength of the case. ${ }^{137}$

\section{The law of procedure}

\subsection{Pleading requirements}

Access to information and disclosure of documents are "information revelation mechanisms" 138 vital for the success of a stand-alone or follow-up litigation. It is often overlooked that these mechanisms will only be triggered if plaintiffs master the initial threshold of stating their case in accordance with national pleading requirements, respecting burden of proof rules. Art. 2 of Regulation (EC) 1/2003 places the burden of proving an infringement of the competition rules on "the party or authority alleging (an) infringement". EU law is silent on standards of proof for proceedings before the Member States' courts; it does not offer much guidance on the level of certainty national judges will have to observe in establishing the facts of the case. ${ }^{139}$ Although national judges are under a general duty not to infringe the "general principles of (EU) law", ${ }^{140}$ it would seem that the recent jurisprudence of the CJEU and Directive 2014/104/EU do not preclude national courts from interpreting their respective rules of civil procedure more liberally with respect to stand-alone or follow-on actions for damages. ${ }^{141}$ In this context, the development of the law is still hampered by a paucity of cases in some jurisdictions. ${ }^{142}$ Within the EU, a policy decision will have to be taken whether pleading standards should be lowered to enable private plaintiffs to move beyond the admissibility stage so that national courts can examine cases on damages more frequently. English courts will defer a finding on the quality of pleading until disclosure has taken place. ${ }^{143}$

\subsection{Burden of proof and cost rules}

In accordance with art. 2 of Regulation (EC) 1/2003 private plaintiffs have to bear the burden of proof for establishing that they have sustained damages due to an infringement of the competition rules. Again, this requires a policy decision to what extent EU law concepts should interfere with national concepts in order to assure the

\footnotetext{
136 Cooper Tire \& Rubber Co. Europe Ltd. v. Shell Chemicals UK Ltd. [2011] C.P. Rep. 1, sub no. 34 et seq. (CA Civ.), sub no. 34 et seq.

137 Ibid., sub no. 43 et seq.

138 Rodger 2014a 43.

139 See recital 9 to Regulation (EC) $1 / 2003$.

140 See on the harmonisation of national rules of procedure under the impact of the ECJ's case law: Cumming, Freudenthal 2010 at p. 6 et seq. Pace 2014241 on the CJEU's "negative harmonisation framework".

141 See Cortese 2014a at p. 156 et seq., offering a comparative survey over Member State practice.

142 Cf. Cumming, Freudenthal 2010 at p. 328 et seq.; Brisimi, Ioannidou 2013656 et seq.

143 See supra sub FN 136.
} 
efficient protection of private parties' rights. ${ }^{144}$ In support of private litigation for damages, burden of proof rules might be supplemented by rebuttable presumptions which would shift the onus to the defendant. In a Dutch case, the then European Court of Justice (ECJ) required Member States' courts to grant an application for the annulment of an arbitral award in breach of the competition rules: National law had allowed the annulment for reasons of public policy. ${ }^{145}$

Although EU law concepts will be creeping into the interpretation of national rules of civil procedure, the European Court will not go as far as redefining national rules on res judicata. ${ }^{146}$ The CJEU will not stigmatise national courts either which allow additional evidence in follow-on proceedings, although the Commission's decision may not be completely overridden. ${ }^{147}$ If stand-alone and follow-on litigation is to add to enforcement of competition law, national judges need to retain some independence and discretion ${ }^{148}$ at the interface between European rules of substance, national laws of procedure and informational and resource asymmetry.

Member States' laws on procedure follow the English cost rule whereby the losing party pays the costs of the lawsuit, including the costs of the opposite party. ${ }^{149}$ Before ascertaining whether this rule operates as a deterrent to private plaintiffs it is useful to reflect on the various types of litigation in the damages scenario. Follow-on litigation may be brought by competitors in the industry, retailers suffering from the negative effects of a pricing conspiracy, and from individual consumers claiming to have suffered losses from overpriced merchandise. ${ }^{150}$ Although stand-alone litigation is (theoretically) open to plaintiffs pursuing a claim for damages prior to the Commission's determination of anti-competitive behaviour, the cases most likely to be litigated are those where a contractual relationship is challenged for breach of EU competition rules. From a legislative policy perspective the question has to be addressed whether consumer protection calls for the establishment of collective redress mechanisms in the field of EU competition law.

\footnotetext{
${ }^{144}$ For a comparative survey over Member States'rules of evidence see D. Waelbroeck/D. Slater/G. Even-Shoshan, (ashurst, Brussels 31 August 2004), at p. 52 et seq. (available at http://ec.europa.eu/ competition/antitrust/actionsdamages/comparative_report_clean_en.pdf). For an analysis of German pleading and burden of proof rules in private competition law enforcement cases: Westhoff 2010.

145 ECJ, judgment of 1 June 1999, case no. C-126/97, Eco Swiss v. Benetton International, [1999] ECR I-3079 (3093 et seq.) (at no. 37 et seq.).

146 Ibid., at p. I-3095 (at no. 46 et seq.).

147 In Bundeskartellbehörde, Bundeskartellanstalt v. Schenker \& Co. AG et al., Case C-681/11, judgment of the Grand Chamber of 18 June 2013, the CJEU held that a national enforcement agency may refrain from imposing a fine despite a finding of illegality (sub recital 48 et seq.). This does not seem to preclude private parties from suing for damages: Cisotta 201597.

148 Cf. Cisotta 201596.

$149 \mathrm{Cf}$. on the costs of competition law litigation under the current English rules on competition law enforcement: Cumming, Freudenthal 2010290 et seq., 295 et seq.

150 Brisimi, Ioannidou 2013655 et seq.
} 


\subsection{Collective redress}

The European Commission has emphasised the value of collective redress mechanisms for private law enforcement in consumer protection and competition law cases. ${ }^{151}$ This is not to suggest that collective redress will automatically recalibrate informational asymmetries in competition law enforcement. But it is the Commission's tacit assumption that collective redress will alleviate the plight of resource of asymmetries and, hence, reduce the cost of addressing informational asymmetries in complex competition law cases by conferring standing on qualified entities or ad-hoc representative groups. ${ }^{152}$ Qualified entities such as consumer associations, state bodies or associations or ad-hoc groups are thought to police claims which individual claimants might be deterred from pursuing due to the unfavourable cost-value ratio. ${ }^{153}$ Although collective and representative redress mechanisms add clout to competition law, ${ }^{154}$ they cannot escape the policy debate about the scope of private litigation in the face of enforcement activities by the Commission and Member States' antitrust authorities. ${ }^{155}$ In the field of collective redress, this debate will be cloaked as an argument about standing, certification of ad-hoc groups, whose claims organisations pursue, and about opt-in or opt-out devices. ${ }^{156}$ The most recent U.S. experience seems to tilt the scales in favour of restrictions on private enforcement: The Supreme Court's stance on stricter pleading requirements for private damages can be interpreted as an attempt to close the floodgates for class actions for damages in antitrust cases. ${ }^{157}$

\section{Conclusion}

In the EU, competition law enforcement is a multi-player game, staged by public officials, private businesses, consumers, the CJEU and national courts. Informational asymmetries are multi-dimensional and predicated on an interaction between government enforcement officials and private litigators. Nonetheless, public and private enforcement interests often seem to be at war with each other. Access to public documents by private parties by a European-style discovery is vital for stand-

\footnotetext{
151 See recital 7 of the Commission Recommendation of 11 June 2013 on common principles for injunctive and compensatory collective redress mechanisms in the Member States concerning violations of rights granted under Union Law (2013/396/EU), O.J. L 201/60 of 26 July 2013.

152 For a survey over consumer-related collective redress mechanisms in the case law of the Member States: Rodger 2014 b at p. 161 et seq.

153 See Commission of the European Communities, White Paper on Damages actions for breach of the EC antitrust rules (COM(2008) 165 final, Brussels 2 April 2008) and id., Green Paper on Damages for breach of the EC antitrust rules (COM(2005) 672 final, Brussels, 19 December 2005), and analysis by van Uytsel 201257 et seq.

154 See van Uytsel 2012 at p. 73 et seq.

155 See passim on class actions in Italian antitrust cases and European repercussions: Cortese 2014c 107 et seq.

156 van Uytsel 2012 at p. 81 et seq., on the tension between individual interests and the public interest.

157 See Bell Atlantic Corporation v. Twombly, 550 U.S. 544 (553 et seq.) (2007).
} 
alone and follow-on litigations, but may severely jeopardise confidential information collected under a leniency programme. The current focus on the effectiveness and equivalence of competition law enforcement tends to obscure that strategies against informational asymmetries need to observe public international law rules, EU norms on confidentiality and access and Member States' laws on procedure and liability. Regrettably, there is very little interaction between these fields of law.

U.S. cases on discovery of EU documents indicate that both, the comity and confidentiality arguments are not immune from the scrutiny of substantive antitrust and corporation laws. In the context of parent-subsidiary relationships and the single-economic entity doctrine courts will allow discovery in order to establish whether there was an intra-enterprise conspiracy to the detriment of third parties. For the CJEU, the single-economic unit theory is no longer unassailable. Private parties may offer evidence to escape liability consequences of the single-economic entity monolith. As a corollary, the Commission's determination of anticompetitive behaviour does not categorically exclude additional evidence in a follow-on proceeding. These details highlight one of the major shortcomings of current attempts to develop a satisfactory regime on reducing informational asymmetries. National laws on procedure and substance, especially on liability, are not superseded by the EU laws on competition law enforcement, and it is far from clear how much 'positive' harmonisation is necessary in the face of the CJEU's concept of 'negative harmonisation'. ${ }^{158}$

Collective redress mechanisms are a useful tool for addressing financing problems for private parties affected by anti-competitive behaviour. But they are predicated on a policy choice how much competition law enforcement should move from the Commission and national antitrust authorities to private parties. If the Commission insists on the priority of public enforcement, national pleading standards for private litigation will not experience a period of leniency.

Acknowledgements Open access funding provided by Max Planck Society.

Open Access This article is distributed under the terms of the Creative Commons Attribution 4.0 International License (http://creativecommons.org/licenses/by/4.0/), which permits unrestricted use, distribution, and reproduction in any medium, provided you give appropriate credit to the original author(s) and the source, provide a link to the Creative Commons license, and indicate if changes were made.

\section{References}

Ahrens B (2015) Case note. Europäische Zeitschrift für Wirtschaftsrecht 2015, 872 et seq

Basedow J, Francq S, Idot LE (2012) Introduction. In: Basedow J, Francq S, Idot LE (eds) International antitrust litigation - conflict of laws and coordination. Hart Publishing, Oxford, 1 et seq

Besanko D, Spulber DF (1989) Antitrust enforcement under asymmetric information. J Econ 99:408 et seq

Bingham AK (1994) Statement before the Committee on the Judiciary. U.S. senate, concerning the International Antitrust Enforcement Assistance Act of 1994, Washington, 4 August 1994

158 See Pace 2014241 et seq. 
Bosch W (2014) The role of fines in the public enforcement of competition law. In: Hüschelrath K, Schweitzer H (eds) Public and private enforcement of competition law in Europe-legal and economic perspectives. Springer, Berlin, 53 et seq

Brisimi V, Ioannidou M (2013) Stand-alone damages actions: insights from Greece and Cyprus. In: E.C.L.R. (34(12)), 645

Buttigieg E (2009) Competition law: safeguarding the consumer interest-a comparative analysis of US antitrust law and EC competition law. Wolters Kluwer, Alphen aan den Rijn

Cisotta R (2015) Some considerations on the last developments on antitrust damages actions and collective redress in the European Union. Compet Law Rev 10:81 et seq

Cortese B (2014a) Defining the role of courts and administrative bodies in private enforcement in Europe: United in diversity? In: Cortese B (ed) EU competition law between private and public enforcement. Wolters Kluwer, Alphen an den Rijn, 111 et seq

Cortese B (2014b) Piercing the corporate veil in EU competition law: the parent subsidiary relationship and antitrust liability. In: Cortese B (ed) EU competition law between private and public enforcement. Wolters Kluwer, Alphen an den Rijn, 73et seq

Cortese B (2014c) The difficult relationship between administrative authorities and the judiciary in antitrust private enforcement. In: Cortese B (ed) EU competition law between private and public enforcement. Wolters Kluwer, Alphen an den Rijn, 95 et seq

Council and the Commission Joint Statement of the on the Functioning of the Network of Competition Authorities (2002)

Cumming G, Freudenthal M (2010) Civil procedure in EU competition cases before the English and Dutch Courts. Wolter Kluwer, Alphen aan den Rijn

Destautels-Stein J (2008) Extraterritoriality, antitrust, and the pragmatist style. Emory Int Law Rev 22:499 et seq

Eger T (2007) Korreferat zu Gerhard Wagner. In: Eger T, Schäfer H-B (eds) Ökonomische Analyse der europäischen Zivilrechtsentwicklung. Mohr Siebeck, Tübingen, 665 et seq

Eger T, Weise P (2010) Some limits to the enforcement of antitrust law: a Grumbler's View on Harm and Damages in hard cartel prices [2010] In: G.C.L.R., 151 et seq

EU Commission (2004) Notice on the co-operation between the Commission and the courts of the EU Member States in the application of Articles 81 and 82 EC (2004/C 101/04), O.J. L 101/54 of 27 April 2004

EU Commission (2014a) Commission Staff Working Document, Enhancing competition enforcement by the Member States' competition authorities: institutional and procedural issues (SWD(2014) 231/4)

EU Commission (2014b) Communication from the Commission to the European Parliament and the Council, Ten Years of Antitrust Enforcement under Regulation 1/2003: Achievements and Future Perspectives

EU Merger Working Group (2010) Merger review

Faull J, Nikpay A (eds) (2014) The EU law of competition, 3rd edn. Oxford University Press, Oxford

First H (2008) The Vitamins case: cartel prosecutions and the coming of international competition law. Antitrust Law J 68:711 et seq

Goldman CS, Hersh C, Witterick CL (2005) Comity after Empagran. Antitrust 18:6 et seq

Hüschelrath K (2014) Public enforcement of anti-cartel laws. In: Hüschelrath K, Schweitzer H (eds) Public and private enforcement of competition law in Europe-legal and economic perspectives. Springer, Berlin, 9 et seq

Hylton KN (2002) An asymmetric-information model of litigation. Int Rev Law Econ 22:153 et seq

Iontecheva J (2001) Sovereignty on our terms. Yale Law J 110:885 et seq

James CA (2001) International antitrust in the 21st century: cooperation and convergence. Address before the OECD Global Forum on Competition, Paris, 17 October 2001

Kwan J (2014) The damages directive: end of England's eminence? E.C.L.R. 36:455 et seq

Miller SR, Nordlander K, Owens JC (2010) The CPI Antitrust J. March 2010 (1), 2 et seq

Munari F (2014) Antitrust enforcement after the entry into force of Regulation No. 1/2003: the interplay between the commission and the NCAs and the need for an enhanced role of the National Courts. In: Cortese B (ed) EU competition law between private and public enforcement. Wolters Kluwer, Alphen an den Rijn, 111 et seq

Newman N (2014) The costs of lost privacy: consumer harm and rising economic inequality in the age of Google. William Mitchell Law Rev 40:849 et seq

OECD (2014a) Recommendation of the OECD of 16 September 2014 concerning international cooperation on competition investigations and proceedings [C(2014)108] 
OECD (2014b) Challenges of international co-operation on competition law enforcement

OECD (2014c) Recommendation concerning international co-operation on competition investigations and proceedings

Pace L (2014) The court of justice 'Antitrust Enforcement Negative Harmonisation Framework' and the CDC and Pfleiderer judgments: 'Another Brick in the Wall'. In: Cortese B (ed) EU competition law between private and public enforcement. Wolters Kluwer, Alphen an den Rijn, 241 et seq

Pénard T, Squam S (2002) Collusions et politique de la concurrence en information asymétrique. Annales d'Économie et de Statistique No. 66, 209 et seq

Picker RC (2007) Twombly, Leegin, and the Reshaping of Antitrust. Supreme Court Rev 161 et seq

Rodger B (2014a) Institutions and mechanisms to facilitate private enforcement. In: Rodger B (ed) Competition law comparative private enforcement and collective redress across the EU. Wolters Kluwer, Alpena an den Rijn, 23 et seq

Rodger B (2014b) Collective redress mechanisms and consumer case law. In: Rodger B (ed) Competition law comparative private enforcement and collective redress across the EU. Wolters Kluwer, Alpena an den Rijn, 73 et seq

Sokol DD (2012) The strategic use of public and private litigation in antitrust as business strategy. South Calif Law Rev 85:689 et seq

Van Uytsel S (2012) Collective action in a competition law context-reconciling multilayer interests to enhance access to justice? In: van Uytsel S, Wrbka S, Siems M (eds) Collective actions-enhancing access to justice and reconciling multilayer interests? Cambridge University Press, Cambridge, 57 et seq

Wagner G (2007) Schadensersatz bei Kartelldelikten. In: Eger T, Schäfer H-B (eds) Ökonomische Analyse der europäischen Zivilrechtsentwicklung. Mohr Siebeck, Tübingen, 605 et seq

Westhoff J-P (2010) Der Zugang zu Beweismitteln bei Schadensersatzklagen im Kartellrecht Nomos Universitätsschriften Recht 674. Nomos Verlag, Baden-Baden 